\title{
“The Difficultest Rigor”: Writing about Wallace Stevens
}

\author{
Wallace Stevens, New York, and Modernism \\ Edited by Lisa Goldfarb and Bart Eeckhout \\ Routledge, 2012.184 pages
}

\author{
The Figure Concealed: Wallace Stevens, Music, and Valéryan Echoes \\ by Lisa Goldfarb \\ Sussex Academic Press, 2011. 228 pages
}

Tony Sharpe

"We have grown weary of the man that thinks. / He thinks and it is not true" (Collected 167). Stevens's lines from "Sombre Figuration" define the wrong kind of mental activity: laborious cerebration merely circulating in "The cycle of the solid" (168). By contrast, "The man below / Imagines and it is true, as if he thought / By imagining, anti-logician, quick / With a logic of transforming certitudes" (167). Ideally, such transfigurational logic might operate, as by epiphany, to "make the visible a little hard / To see" (275), dissolving the firm boundaries of knowledge so that "we ... behold / The academies like structures in a mist" (334). Most of us who write about Stevens operate from within those academies, and should probably feel chastened by the consistency of his disdain for what we do ("how they keep alive is more than I can imagine," was his comment on the dons of Princeton [Letters 392]). Our revenge has been to visit on his work a critical response that nearly fifty years ago Frank Kermode diagnosed as "a characteristic failure of our graduate schools" (334). This response presents Stevens as "a tiresome doodler with a vast but not profoundly interesting body of Thought, which he has never quite got round to articulating"; of one example, Kermode complained that "what it does is to take the meta-metaphysical mutter of Stevens and make it explicit" (355).

The situation has been greatly and positively transformed in the intervening decades, but not so much as to render Kermode's remonstrances wholly obsolete. For a different example, when the editors of the current (eighth) edition of the Norton Anthology of American Literature reduced their already insufficient Stevens representation, they omitted 
his impassioned utterance "A Postcard from the Volcano," while retaining the programmatically explicable "Of Modern Poetry." This presumably reflects the academy's persistent appetite for poems that can be made "explicit." But it does not reflect the Stevens who insisted in a letter that "a poem must have a peculiarity, as if it was the momentarily complete idiom of that which prompts it" (Letters 500), nor even the Stevens who later chose to omit "Sombre Figuration" (as part of Owl's Clover) from his 1954 Collected Poems. That volume he opened with "Earthy Anecdote" (the first poem in Harmonium, over thirty years earlier) and closed with "Not Ideas About the Thing But the Thing Itself." To follow Stevens's sequence was, then, to start by encountering his "firecat" and to finish, in the last line of Collected Poems, at "A new knowledge of reality." The first, we might suppose, conduces to the second, but a reductive tendency in some criticism over-focuses on a summarized epistemology and overlooks the transforming certitudes, emblematized by that Oklahoman encounter between momentarily complete firecat and evasive bucks following their herd-instinct. This poem of ever-repeatable process nonetheless requires both bucks and firecat for its proper activation.

"Earthy Anecdote" thus functions as Stevens's welcome-mat poem in much the same way that "The Love Song of J. Alfred Prufrock" does for Eliot, and in their different modes each offers the intending reader an invitation that is also part challenge: begin, ephebe- but watch out for the firecat. It's unrealistic to expect literary criticism to dream much of baboons and periwinkles, but what I look for in a book about Stevens is some responsiveness to why he thought it might be good to do so. An associated problem that Kermode drew attention to in his piece (a review of the then newly published Letters) was the tendency to treat Stevens's oeuvre as a kind of holy writ, from any part of which edifying pronouncements could be extracted in support of the critical case being made. This evades the incontestable fact that not all Stevens's poems are equally good, and raises the question whether it is honest to pretend otherwise, or to use a quotation from a poem one believes to be second- or even thirdrate Stevens simply because it illustrates in a conveniently explicit way the point one wishes to make. I have myself already transgressed in that regard, by citing "Sombre Figuration"; of course, the lines quoted served my turn, and are in many ways characteristic of his thinking and writing. But it is as well to remember that Randall Jarrell, reviewing The Auroras of Autumn, described its poetry as "characteristic" (121) in a pejorative 
sense: for Stevens-being-Stevens is not invariably something to celebrate. For that reason, I admire Jarrell's inclination to make a list of his favorite Stevens poems, and endorse his judgement that, at his best, the poet is "all windhover and no Jesuit" ("Collected" 187). Stevens's "Bird With the Coppery, Keen Claws" blindly munches the dry shell of metaphysical speculation with its "keen intellect," but its plumage is spectacularly beautiful.

Long ago, Helen Vendler insisted on the note of austerity rather than of gaudiness and profusion as sounding Stevens at his truest, and I'm not trying belatedly to reverse her judgement. For the fact is that gaudiness and austerity are often inextricably intertwined in his poetry, the "gaiety of language" solacing our "poverty" and "malheur" as we decorate our cemetery or send postcards from our volcano. The important thing is to appreciate that the poetry is seldom an arrival at a finished thought or a "final belief," so much as a medium of mental being in which endoriented thinking finds itself disturbed by fortuitous imagining, as when firecat confronts bucks to produce the poem: "the difficultest rigor is forthwith / On the image of what we see, to catch from that / Irrational moment its unreasoning" (344-45).

What would it be, then, to think truly about Stevens, and how well do the two books under review catch his "unreasoning"? Wallace Stevens, New York, and Modernism, co-edited by Lisa Goldfarb and Bart Eeckhout for the Routledge Studies in Twentieth-Century Literature series, contains nine essays book-ended by an Introduction and a "Coda." These pieces collectively take as their instigating focus the period Stevens spent in New York: those sixteen years between Harvard and Hartford during which he failed as a journalist, studied in law, failed in private practice, embarked on the protracted courtship of Elsie Moll (which relationship caused a permanent rupture with his father), eventually married her and had laid the foundations of what might fairly be described as a failing marriage before, in his late thirties, he began to shape success, professionally in the insurance business and, as a writer, by composing the poems of his early maturity, including the anthology staple "Sunday Morning." Lisa Goldfarb's monograph, The Figure Concealed: Wallace Stevens, Music, and Valéryan Echoes, published by Sussex Academic Press, focuses, its cover declares, "on the resonance of Valéry's musical ideas in Stevens" poetic theory and practice." In doing this it develops at much greater depth and detail comparisons between the two poets that previous commentators 
had indicated rather than substantiated. The essays (which arose out of a conference) take as their starting-point a segment of Stevens's life, whereas Goldfarb's study starts from the writing. But both emphasize that the connections to be drawn, between poet and city and between Valéry and Stevens, are matters of fruitful suggestion rather than products of a naive model of direct influence.

Such a strategy requires a ground-clearing that acknowledges that there may not, in reality, be so much ground to clear: one essayist confesses that "unlike the work of almost any other major modernist poet who spent time in New York, Stevens's poetry seems to erase this architectural modernity or consistently turn away from it" (88); another, that trawling Stevens's work "for a proper collection of poetic evocations of New York proves to be a rather disappointing task" (133); Goldfarb, in her book, concedes that "there is little evidence that Stevens read Valéry's prose and poetry in a systematic manner" (5). But of course, with Stevens, an "absence in reality" can amount to an intense imaginative presence, and his de-solidification of architectural petrifaction or aversion from any systematic manner are characteristic manoeuvres. Some of these essays usefully consider the poet's links to Henry James, and when Stevens is functioning at one extreme of his range he is indeed reminiscent of the hyper-subjectivity of the narrator of The Sacred Fount, who confesses that "it would have been almost as embarrassing to have to tell them how little experience I had had in fact as to have had to tell them how much I had had in fancy" (79).

Stevens's links with Henry (rather than William) James have constituted, Goldfarb and Eeckhout's volume correctly contends, an underexplored topic (albeit one addressed by a recent number of the Wallace Stevens Journal). The two writers' resemblances lie less, maybe, in their attitudes to New York than in their ideas about art: in 1945 Stevens cited a "precious sentence" from James's Notebooks in a letter to José Rodriguez Feo having to do with living "in the world of creation" (Letters 506), and in 1951 he (mis)quoted James's celebrated protest to H. G. Wells ("It is art that makes life") in "The Relations between Poetry and Painting" (Collected 747). Some contributors explore Stevens's earlier engagement with the novelist, when his reading of Washington Square might have set up uncomfortable personal resonances - although an additional discomfort in contemplating James may well have lain in the novelist's successful European domicile, contrasting with Stevens's own thwarted aspirations to 
visit France. One essay appears to confuse The American with The Ambassadors (125), but it is perhaps unfair to cavil at a volume which is agreeably light in touch, citing Woody Allen in its introduction and ending with a humorous but not pointless "Coda" which uses extracts from a late letter recounting a visit to New York to assemble a "New York School" poem. The need to avoid the already well-worked-over years-when Stevens mingled with the avant-garde in Walter Arensberg's salon, was reputedly menaced by Elsa von Freytag-Loringhoven, and met Marcel Duchampmight have produced a distorted account; but in fact the attention paid to his artistic tastes and their conservatism, exemplified by an appetite for "representational painting" (41) or the later construction in his Hartford home of an ambience "symbolically resisting "professional modernism"" (157), is productive. It is also helpful to have insights into figures like Christopher Shearer and Adolph Weinman, successive tutelary figures in the arts for young Stevens.

While it is indeed striking to encounter phraseology of "ghostly street-lamps" and "vacant streets" in a Stevens poem written the year before the earliest of Eliot's "Preludes," it may be germane to recall that Eliot was nine years younger (and therefore getting there faster). In any case, Stevens's 1908 "Chiaroscuro," with its marked contrast between an inhospitable cityscape and an interior full of erotic potential, seems directly to prefigure "Tea." The essay in which "Chiaroscuro" is cited (25) also recycles Robert Buttel's contention that the poem "Floral Decorations for Bananas" can be compared to Duchamp's notorious "Nude Descending a Staircase" (28), which strikes me as riotously unconvincing: Marianne Moore in her review of Harmonium was much nearer the mark in mentioning "Douanier" Rousseau. The essay on Stevens and dance does not persuade that there is as substantial a subject here as there would be in the case of Eliot, but perhaps misses a trick by not noticing that Carlos's final off-stage leap through a window, in the early play "Carlos and the Candles," probably alluded to Nijinsky's spectacular manoeuvre at the end of Le Spectre de la Rose.

Drawing such comparisons requires a light touch: when Stevens recorded "I hurried through the Mall or Grand Alley or whatever it is" (qtd. in Goldfarb and Eeckhout 66), this does not suggest any urgent exactitude in respect of New York's environs. His ability to "erase" so much of the astounding architectural development he must have been witnessing perhaps suggests the kind of inattention that would later enable him to assert 
that there were "five" columns supporting the portico of his insurance company's headquarters (through which he had been passing for years), when in fact there are six (Letters 283). This interesting volume makes a good case for the diverse kinds of impact Stevens's early residence in New York may have had, but it also seems as if there was a conflict, a resistance involved, which can possibly be connected to his yearnings toward France: his sneer at "New-York, far out on the bleak edge of the world" (Letters 117) derived, after all, from its not being Paris. Yet for all his pretensions, he sensed that in New York he was being "Americanized" in necessary ways, and these essays imply, perhaps, that he was the city's before the city was his.

But you don't have to choose between American Stevens and Francophile Stevens, any more than you choose between bucks and firecat. If he could sneer at New York, Stevens could much later take pleasure in an article that "makes Valéry's skeleton ring," turning from it, however, to wonder "Who the heck cares?" (Letters 624). That Lisa Goldfarb cares about both poets and their interconnections is apparent on each page of her painstaking study which, chapter by chapter, establishes the case for appositioning them, largely by means of their "musical poetics" (10). As a critical strategy, this is valuable for its alertness to the poem as a process as much musical as philosophical, and for suggestively revealing Stevens as another practitioner who, like Valéry, conceded "the primacy of sound over meaning" (15). This is less a matter of succumbing to the bawds of euphony than it is of appreciating the extent to which, in Stevens's poetry, music becomes a mode of thinking as well as a mode of revealing desire: "Poetry is, for Stevens as forValéry, a means of demonstrating, at once, the limitations of philosophy and the promises of musical-poetic language as a response to and even a means of resolving his philosophic questions" (81).

For both poets, any such resolution lies not in an evolved philosophical system so much as in a "poetics of variation" (81) which foregrounds process. A poem, suggests Valéry, involves "une liaison continuée entre la voix qui est et la voix qui vient et qui doit venir" (qtd. in Goldfarb 105). Similarly, what Stevens once called "the voice that is great within us" (Collected 112) is the assumption of a temporary power. Thus Goldfarb notes that "Much like Valéry's voice, poised in an uneasy balance between discourse and music, Stevens insists that the voice to which we listen in poetry is not the voice of ordinary speech: it is the voice of an "actor," a 
"figure concealed,"'an orator" (115). Goldfarb's arguments and extended comparisons between the two poets are too dense to be adequately summarized here, but her continuous emphasis is away from summative meanings and toward the poem understood as an act of thinking in which sonic texture is, importantly, part of its signification. This leads toward some very suggestive areas, such as an implied ascent from noise to sound to harmony, and her contention that "At the heart of Stevens's erotic poetics lies his understanding of the role of sound" (187). If one of the "Adagia" asserts that "In poetry, you must love the words, the ideas and images and rhythms with all your capacity to love anything at all" (Collected 902), such "love" might be glossed by Stevens's later insistence in "The Noble Rider and the Sound of Words" that "above everything else, poetry is words; and that words, above everything else, are, in poetry, sounds" (663).

It is not a question of Valéry's supplanting figures like Emerson (who equally lies behind Stevens's phrase "skeptical music" and his poem "The Red Fern"), or Coleridge, or even Pater, but of augmenting them as a means of "understanding Stevens's musicality" (2) and revealing its unexpected magnitudes. Valéry's famous definition of the poem as "cette hésitation prolongée entre le son et le sens" (637) is a formula that proffers a distinction between sound and sense at the level of meaning while semi-humorously withdrawing it by the near-homophony, in French, of its two terms: such "hesitation" is not the paralysis of indecision but a productive lingering, like the energetic shuttle of alternating current or Keats's negative capability. In Stevens, a line such as "Inanimate in an inert savoir" is one that, whilst indicating a sort of semantic entropy, is acoustically creative, energized by an audible dance of consonants and assonants as well as its playful reaching toward French. There never really is any utterly "Plain Sense of Things" in Stevens, in whose work even a grim statement of finality is susceptible of musical analogy: when, for example, "a wasted figure, with an instrument / Propounds blank final music" (Collected 315).

"The reason we go to poetry is not for wisdom, but for the dismantling of wisdom": Jacques Lacan's dictum (quoted by Anne Carson in her 2004 Paris Review interview) would apply perfectly to Stevens. Goldfarb's study responds to the "delicate clinkings" that in Stevens's poetry counteract the two-dimensionality of "flat appearance" the more effectively for being "not explained" (Collected 297). I would personally have liked 
to have seen a greater sense of his playfulness animate her readings, and I don't necessarily admire all the poems that she does; but both her book and, in its different way, Goldfarb and Eeckhout's volume of essays helpfully move us away from the wearisome "man that thinks" toward a figure of more intriguingly capable imagination. (It is pleasing, too, to note that both books appear under British imprint.) "He mutter spiffy," was part of John Berryman's qualified tribute ("So Long? Stevens"; Dream Song 219) to Stevens. The useful tendency of these books is to place before us a poet that matters rather than one who mutters.

\section{Works cited}

Berryman, John. His Toy, His Dream, His Rest. London: Faber, 1969.

Carson, Anne. "The Art of Poetry No. 88." The Paris Review 171 (2004). 4 Dec. 2012.

James, Henry. The Sacred Fount. 1901. London: Rupert Hart-Davis, 1959.

Jarrell, Randall. "The Collected Poems of Wallace Stevens." The Achievement of Wallace Stevens. Ed. Ashley Brown and Robert Haller, New York: Gordian Press, 1973.

—. "Reflections on Wallace Stevens." Poetry and the Age. London: Faber, 1996.

Kermode, Frank. Modern Essays. London: Fontana, 1971.

Stevens, Wallace. Collected Poetry \& Prose. Ed. Frank Kermode and Joan Richardson. New York: Library of America, 1997.

- Letters of Wallace Stevens. Ed. Holly Stevens. London: Faber, 1967.

Valéry, Paul. Rhumbs. Tel Quel. CEuvres. Tome II. Paris: Pléiade, 1960. 